\title{
The population dynamics of the parasitic copepode Lernaeocera lusci (Bassett-Smith, 1896) on its definitive host
}

\author{
P. A. Van Damme ${ }^{1}$, O. Hamerlynck ${ }^{2,3}$ \& F. Ollevier ${ }^{1}$ \\ ${ }^{1}$ Laboratory of Ecology, University of Leuven, Zoological Institute; Naamsestraat 59, \\ B-3000 Leuven, Belgium \\ ${ }^{2}$ Marine Biology Section, University of Ghent; Ledeganckstraat 35, B-9000 Gent, Belgium \\ and \\ ${ }^{3}$ Center for Estuarine and Coastal Ecology; Vierstraat 28, NL-4401 EA Yerseke, \\ The Netherlands
}

\begin{abstract}
The mesoparasitic copepod Lernaeocera lusci (Bassett-Smith, 1896) was recovered from first-year bib (Trisopterus luscus L.) in the Voordelta (Southern Bight of the North Sea) from May until December 1989. Analysis of the seasonal abundance and of the population structure showed that transmission of infective stages to bib mainly occurred from June to September. From September to December the overall prevalence fluctuated around $70 \%$. Maximum parasite population size $\left(47 / 10^{4} \mathrm{~m}^{2}\right)$ and the highest total egg number were recorded in September and October, respectively. It was found that total parasite mortality was significantly influenced by mortality of hosts carrying parasites. Natural mortality probably contributed a small percentage to total parasite mortality. Calculation of the temporal mean-variance regression equation revealed that the parasites were aggregated within the definitive host population.
\end{abstract}

\section{INTRODUCTION}

Some of the most conspicuous parasite species of the North Sea belong to the genus Lernaeocera (Pennellidae, Crustacea). Several authors have studied the population dynamics of Lernaeocera branchialis, a pathogenic parasite which infects economically important gadoid species such as whiting (Merlangius merlangus) and cod (Gadus morhua) (e.g. Whitfield et al., 1988; Pilcher et al., 1989). In contrast, comparatively little information is available on a related species, Lernaeocera lusci, which infects the bib (Trisopterus luscus). Some authors even doubted the validity of the latter parasite species (Heegaard, 1947; Bastide-Guillaume et al., 1985). Recently, Tirard (1991) studied both species by enzyme electrophoresis and decisively confirmed both $L$. branchialis and $L$. lusci as valid species. She also proposed a morphological distinguishing characteristic: antennary processi are absent in $L$. branchialis but are present in $L$. lusci.

Aspects of the biology of $L$. lusci have been studied by Evans et al. (1983), Eiras (1986) and Tirard (1991). The life cycle of this species was studied in detail by Slinn (1971), who found that sole Solea solea (L.) is the typical intermediate host in the North Sea. Several authors reported on the (broad) host specificity towards the definitive host 
(Kabata, 1963; Boxshall, 1974; Kabata, 1979; Van Damme, 1993) and on the site specificity (Evans et al., 1983; Eiras, 1984) of L. lusci. However, the population dynamics of this species have received little attention.

The seasonal abundance of $L$. lusci was studied in the Voordelta, a coastal area in the Southern Bight of the North Sea (Fig. 1). Within this area, $0+$ bib (T. luscus) is the most important host of $L$. lusci. The specific objectives of this study are to (1) investigate seasonal variations in prevalence and mean intensity, (2) study the seasonal variations in population structure of $L$. lusci, and (3) discuss observed dispersion patterns of L. lusci on $0+T$. luscus.

\section{MATERIAL AND METHODS}

First-year bib, which entered the Dutch coastal area in spring, were captured using a 3-m beam trawl equipped with a shrimp net. Eight samples of $0+$ bib were collected monthly from May 1989 to December 1989. Samples were taken in the ebb tidal delta of the former Grevelingen estuary and in the ebb tidal delta of the Oosterschelde (Fig. 1). Water surface temperatures are given in Figure 2. On board, fish were anaesthetised in a benzocaine solution and preserved in $7 \%$ formalin immediately after capture. After 3 months, fish were transferred to $70 \%$ ethanol, and their total length (TL) was measured. The gill cavity was then checked for parasites. The number of fish examined for the occurrence of $L$. lusci and the mean total length of the $0+$ bib cohort are given in Figure 3.

The adult females of $L$. lusci were classified according to a nomenclature proposed by Van Damme \& Hamerlynck (1992), which is a modification of the staging system initially proposed by Sproston \& Hartley (1941). Table 1 summarizes the diagnostic characters of the substages. This nomenclature is based on the distinction between subadult $(P, U, W)$, adult stages $(X)$ and dead parasites $(Z)$.

The terms prevalence ( $\%$ fish infected), abundance (number of parasites/fish) and mean intensity (number of parasites/infected fish) were used according to the recommendations of Margolis et al. (1982). The $Z$ substage was included in the calculations only when explicitly stated.

Spearman Rank Correlations between parasite intensity and total length were calculated, and a non-parametric test (Kruskal-Wallis) was used to investigate whether seasonal differences in parasite abundance occurred.

Fish densities are given as $\mathrm{n} / 10^{4} \mathrm{~m}^{2}$. No corrections were made for net efficiency. Parasite population density at each sampling date was calculated as follows:

$$
P_{t}=a_{t} H_{t}=a_{t} H_{0} e^{-m t}
$$

where

$\mathrm{P}_{\mathrm{t}}=$ parasite population density at time $\mathrm{t}$

$\mathrm{H}_{\mathrm{t}}=$ host population density at time $\mathrm{t}$

$\mathrm{H}_{0}=$ initial host population density at time 0

$\mathrm{a}_{\mathrm{t}}=$ parasite abundance at time $\mathrm{t}$

$\mathrm{m}=$ mortality coefficient

The mortality coefficient $\mathrm{m}\left(0.0077 \mathrm{day}^{-1}\right)$ was taken from Hamerlynck \& Hostens (1993). Because the juvenile bib were sampled inefficiently in May (due to mesh size selection), the host density in this month was backcalculated. To calculate the density of mature 


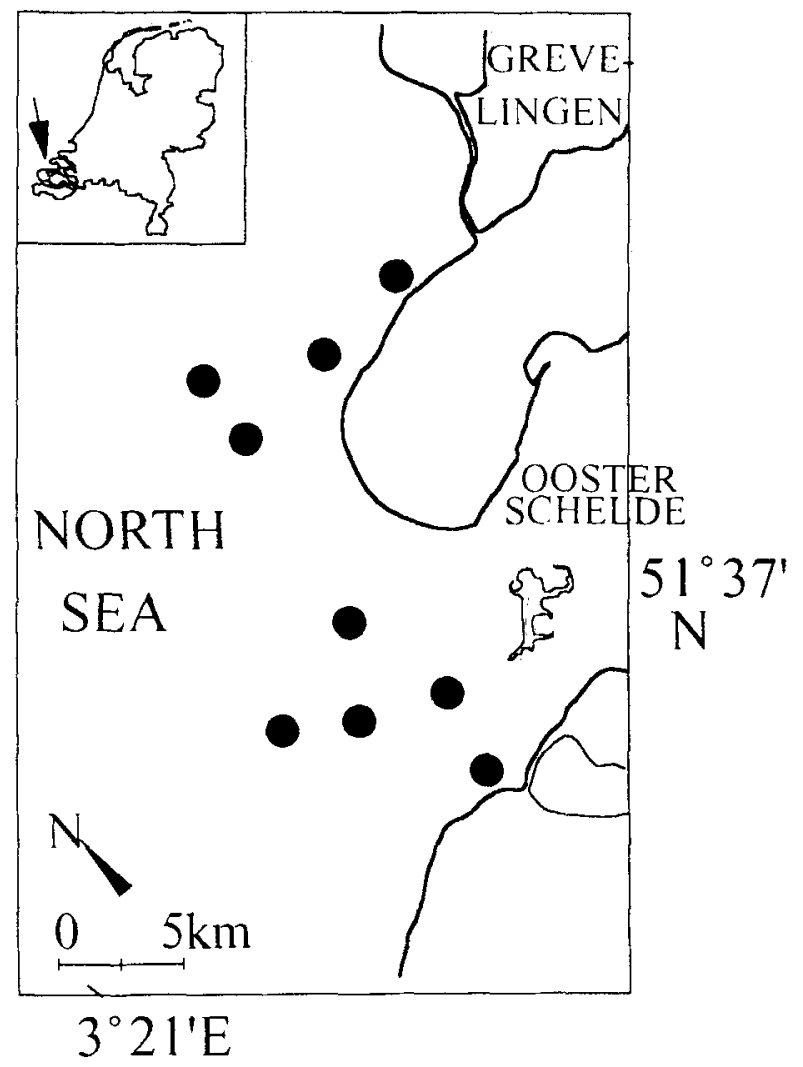

Fig. 1. Map of the study area. The sampling localities are indicated by solid circles

(X stage) parasites $\left(\mathrm{P}_{t}[\mathrm{X}]\right)$ at different time intervals, the same formula was used with $a_{t}(X)$ (abundance of $X$ parasites) instead of $a_{t}$. Egg density at time $t$ was calculated by multiplying parasite density $\left(\mathrm{P}_{\mathrm{t}}[\mathrm{X}]\right)$ with the mean number of eggs per egg-string pair at time $t\left(z_{t}\right)$.

The parasite dispersion patterns were studied by calculating the variance-to-abundance $\left(I=s^{2} / a_{t}\right)$ ratio (Elliot, 1977). If the individuals are randomly distributed among the samples, a value for this ratio of 1.0 is expected. Statistically significant deviations from 1.0 are termed aggregated ( $>1$ ) or even ( $\mathrm{I}<1$ ) distributions. Deviations from randomness were examined using the test statistic d (Elliot, 1977),

$$
d=\sqrt{2 \chi^{2}}-\sqrt{2 v-1}
$$

with

where

$$
\chi^{2}=s^{2} v / a_{t}
$$

$v=$ degrees of freedom

$\mathrm{a}_{\mathrm{t}}=$ abundance at time $\mathrm{t}$

$\mathrm{s}^{2}=$ variance 


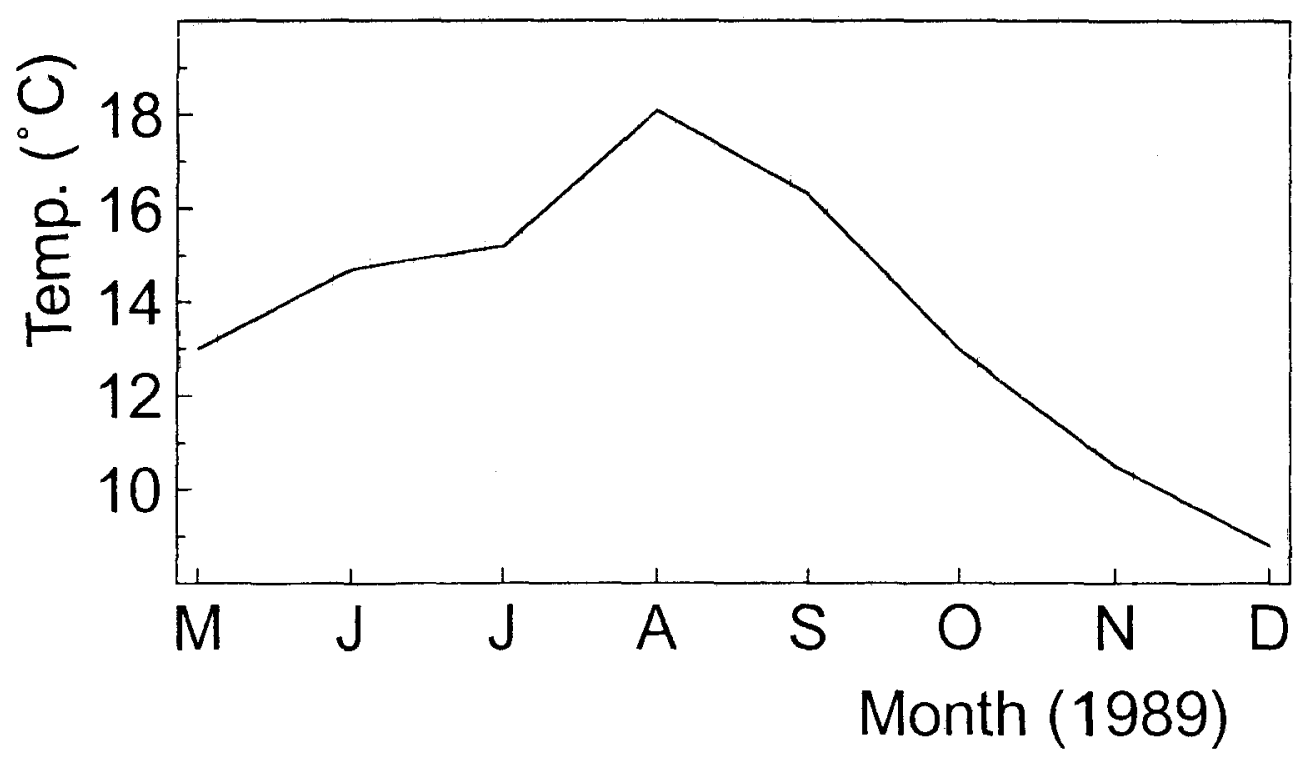

Fig. 2. Water surface temperatures in the Voordelta from May to December 1989

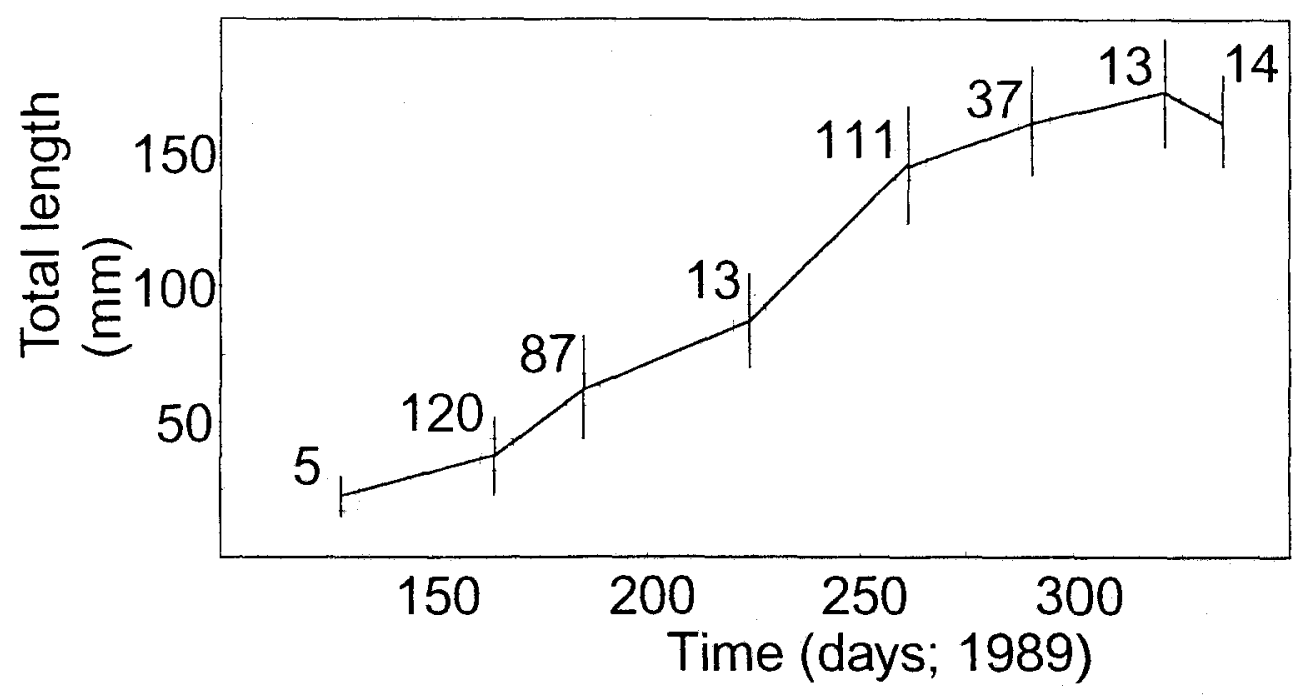

Fig. 3. Increase in mean total length of $0+$ bib in the Voordelta. The standard deviations are indicated by vertical bars. The number of fish examined $(\mathrm{n})$ is shown (after Hamerlynck \& Hostens, 1993) 
Table 1. Classification of adult female Lernaeocera lusci (Bassett-Smith, 1896) on Trisopterus luscus (L.) (after Van Damme \& Hamerlynck, 1992)

\begin{tabular}{|ll|}
\hline Substage & \multicolumn{1}{c|}{ Definition } \\
\hline Pennella (P1) & Straight body, no flexure \\
Pennella (P2) & One point of flexure \\
Immature (U) & Two or three points of flexure \\
Mature pregravid $(\mathrm{W})$ & Genital region fully swollen \\
Mature gravid $(\mathrm{X})$ & External egg strings present \\
$\mathrm{X} 1$ & Immature eggs \\
$\mathrm{X} 2$ & Mature pigmented eggs \\
$\mathrm{Y}$ & External egg strings partly or completely spent \\
Dead parasite $(\mathrm{Z})$ & Remains of holdfast embedded in host tissue \\
\hline
\end{tabular}

At a level of significance of $p=0.05$, values of $-1.96<d<1.96$ indicate a random distribution, and $d>1.96$ indicates an aggregated distribution. Test statistic $d$ was calculated only for large samples $(n>30)$. For small samples $(n<30)$, the $\chi^{2}$ value was compared with the appropriate $5 \%$ significance levels for $v$ degrees of freedom. Furthermore, agreement of the observed frequencies with the Poisson series and with the negative binomial was tested. The parameters of the latter distribution are the abundance $a_{t}$ and parameter $k$. A rough estimate of parameter $k$ was derived from the equation

$$
a_{t}=\frac{a_{t}^{2}}{s^{2}-a_{t}}
$$

For $\mathrm{k}<4$ a better estimate was obtained by the method of maximum likelihood (Elliot, 1977)

$$
\operatorname{nln}\left(1+\mathrm{a}_{\mathrm{t}} / \mathrm{k}^{\prime}\right)=\sum \frac{\mathrm{A}(\mathrm{x})}{\mathrm{k}^{\prime}+\mathrm{x}}
$$

where

$\mathrm{x} \quad=$ particular count

$\mathrm{n}=$ number of fish

$A(x)=$ total number of counts exceeding $x$

Expected frequencies of the negative binomial were calculated by means of the SAS procedure PROC NGBIN $=(p, k, n)$ where $p=1 /\left(1+a_{t} / k\right)$ and $n=$ number of parasites. Expected frequencies of the Poisson model were calculated by means of the SAS procedure PROC POISSON $=\left(\mathrm{a}_{\mathrm{t}}, \mathrm{n}\right)$. The observed distributions were compared with the Poisson series and with the negative binomial by $\chi^{2}$ (goodness-of-fit) tests (Elliot, 1977); Taylor (1961) presented a formula where variance is proportional to a fractional power of the abundance. The exponent $b$ from Taylor's power function

$$
\mathbf{s}^{2}=\mathrm{a}\left(\mathrm{a}_{\mathrm{t}}\right)^{\mathrm{b}}
$$

was used as an index of dispersion and varies from 0 for an even distribution to $+\infty$ for an aggregated distribution. 


\section{RESULTS}

A small number of bib (4\%) in June were infected with Lernaeocera lusci. The prevalence then gradually increased in July and August, followed by a sharp increase in September. From September to December the overall prevalences (Fig. 4A) fluctuated between $68 \%$ (Oct) and $77 \%$ (Nov).

The parasite abundance changed as the prevalence changed (Table 2). Overall temporal changes in abundance were highly significant (Kruskal-Wallis, $\mathrm{P}<0.001$ ). In all months from June to September, significant increases in parasite abundance were found (Kruskal-Wallis; $\mathrm{P}<0.05$ ). The changes in the abundance scores from September to December were not significant (Kruskal-Wallis on paired means; $P>0.05$ ) (cf. Table 2). The mean intensity increased gradually from about 1 (June/July) to a maximum of 4.8 in December.

The Spearman Rank Correlations between parasite intensity and total length of bib are shown in Table 3. A significant positive correlation was only found in June. Although all other correlations were not significant $(P>0.05)$, opposite trends seem to be present in summer versus autumn: from June to August large fish harboured more parasites, and from September to November the largest numbers of parasites were found on smaller fish.

Seasonal patterns in the population densities of both host and parasite are presented in Figure 4. Whereas maximum host population density in the study area was probably highest in May $\left(150 / 10^{4} \mathrm{~m}^{2}\right)$, maximal parasite population density $\left(47 / 10^{4} \mathrm{~m}^{2}\right)$ was recorded in September. In winter, parasite density decreased to a minimum of $15 / 10^{4} \mathrm{~m}^{2}$ (December). The corresponding densities of mature parasites exhibited a similar pattern. Maximum density was found in September $\left(30 / 10^{4} \mathrm{~m}^{2}\right)$.

Pennella larvae (mainly P1) were found from June to October 1989 (Fig. 5). Only a single $\mathrm{P} 1$ stage was found in June. The $\mathrm{X}$ stages were recorded for the first time in July and were found with an increasing frequency from August to December. The $Z$ stages were recorded in low numbers from September to December. The relative occurrences of $\mathrm{X} 1, \mathrm{X} 2$ and $\mathrm{Y}$ substages are presented in Table 4. In July, only $\mathrm{X} 1$ stages were found. From August to December both X2 and $\mathrm{Y}$ stages were found, and the frequency of occurrence of the latter substages fluctuated between $19 \%$ (Nov.) and $29 \%$ (Sep.). The mean number of eggs in the consecutive months $\left(z_{t}\right)$ is shown in Table 2 . The maximum number of eggs found in one individual was 2504 (December 1989). The highest total egg number within the Voordelta area was found in October $1989\left(35000 / 10^{4} \mathrm{~m}^{2}\right)$ (Fig. 4C).

The variance-to-abundance ratios $\left(I=s^{2} / a_{t}\right)$ were significantly different from 1 , except in June and July when they approached unity. Highly aggregated patterns were recorded in November $(\mathrm{I}=4.9$ ) and in December $(\mathrm{I}=3.9)$. The highest number of parasites collected from one fish (14) was found in November 1989. The observed frequencies and the corresponding expected frequencies according to a negative binomial (to which best agreement was found, see Table 2) are shown in Figure 6. The parameter $\mathrm{k}$, estimated by the maximum-likelihood method, and the results of the $\chi^{2}$ test for agreement with the negative binomial are shown in Table 2. Between August und December this model fits well to the observed frequencies. Agreement with the Poisson series was only accepted in 3 months. The temporal regression equation describing the relation between variance $(\mathrm{y})$ and abundance $(\mathrm{x})$ is $\log \mathrm{y}=0.4+1.4 \log \mathrm{x}\left(\mathrm{n}=7, \mathrm{r}^{2}=\right.$ 0.98). 

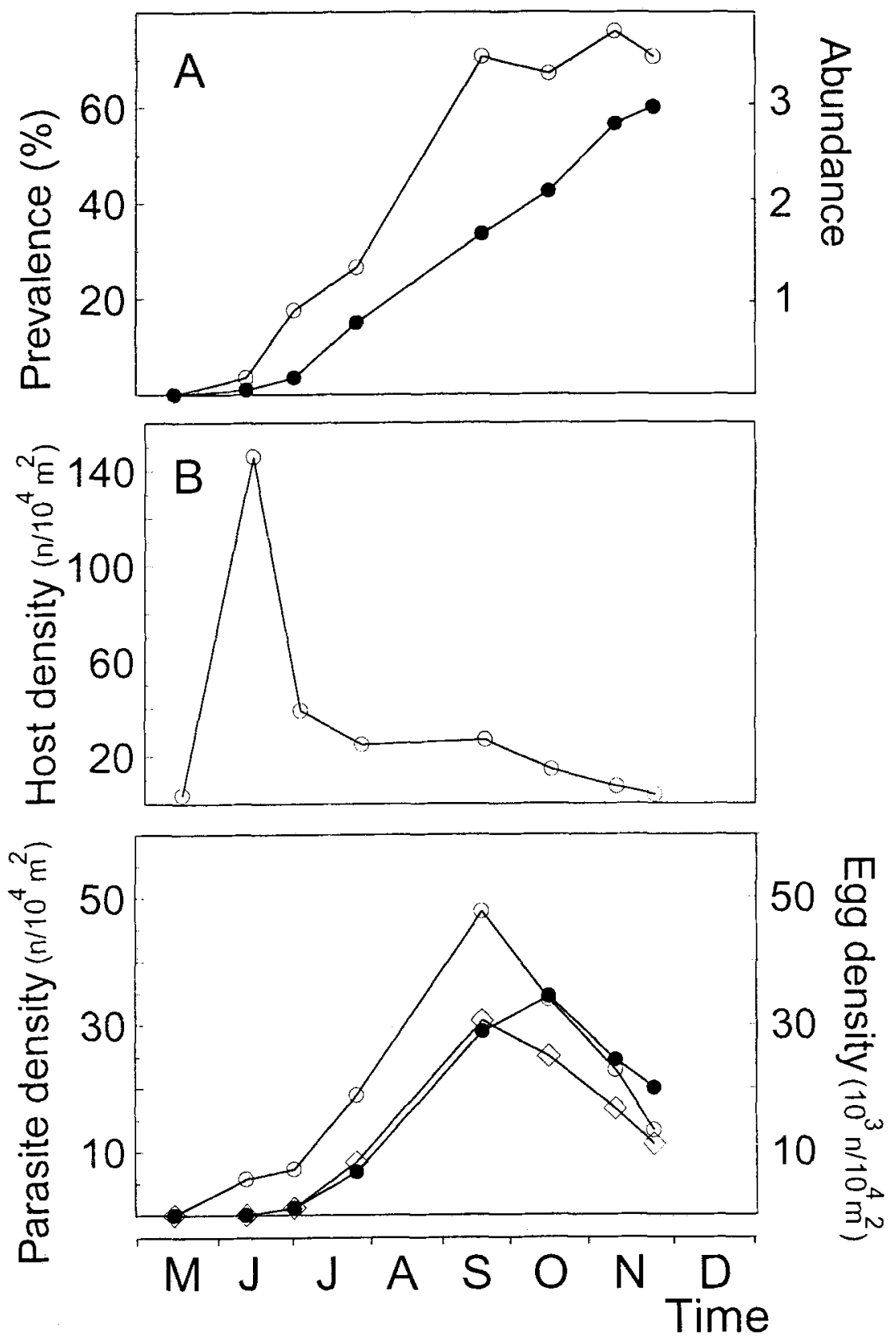

Fig. 4. Seasonal patterns in the infection of Trisopterus luscus by Lernaeocera lusci. A: Prevalence (open circles) and abundance (solid circles). B: Host population density. C: Population density of all parasites (open circles) and mature parasites (squares), and egg density (solid circles) 
Table 2. Parasite abundance $\left(a_{t}\right)$, variance to abundance ratio $\left(I=s^{2} / a_{1}\right)$, test statistic $d$, parameter $k$ of the binomial distribution, mean number of eggs $\left(\mathrm{z}_{t}\right)$ and agreement with the Poisson series (PO) and the negative binomial (NB) of Lernaeocera lusci on Trisopterus luscus from June to December 1989 in the Voordelta

\begin{tabular}{|c|c|c|c|c|c|c|c|c|}
\hline & $\mathrm{n}$ & $a_{t}$ & I & $d$ & k & $\mathrm{PO}$ & NB & $\mathrm{z}_{\mathrm{t}}$ \\
\hline June & 120 & $0.04^{c}$ & 0.97 & -0.29 & - & $\mathrm{PO}$ & - & - \\
\hline July & 87 & $0.18^{\mathrm{bc}}$ & 1.00 & -0.36 & - & $\overline{\mathrm{PO}}$ & - & 873 \\
\hline Aug. & 43 & $0.74^{\mathrm{b}}$ & $3.33+$ & 7.51 & 0.32 & $\overline{\mathrm{PO}}$ & NB & 963 \\
\hline Sept. & 111 & $1.68^{\mathrm{a}}$ & $1.99+$ & 6.03 & 1.71 & 0 & $\overline{\mathrm{NB}}$ & 952 \\
\hline Oct. & 37 & $2.11^{\mathrm{a}}$ & $2.87+$ & 5.82 & 1.13 & 0 & $\mathrm{NB}$ & 1365 \\
\hline Nov. & 13 & $2.85^{\mathrm{a}}$ & $4.85+$ & 5.79 & 0.74 & $\mathrm{PO}$ & $\overline{\mathrm{NB}}$ & 1447 \\
\hline Dec. & 14 & $3.43^{\mathrm{a}}$ & $3.85+$ & 4.80 & 1.20 & 0 & $\overline{\mathrm{NB}}$ & 1643 \\
\hline \multicolumn{9}{|c|}{$\begin{array}{l}\text { Abundance scores with common superscript are not significantly different (Kruskall-Wallis on } \\
\text { paired means, } \mathrm{P}>0.05) \\
\text { Variance to mean ratios marked with }+ \text { are significantly different from } 1 \\
\mathrm{PO}=\text { agreement with the Poisson series }(\mathrm{P}>0.05) ; \mathrm{NB}=\text { agreement with the negative binomial } \\
(\mathrm{P}>0.05) ; 0=\text { no agreement }(\mathrm{P}<0.05) \text {; the model which gave the best agreement is underlined }\end{array}$} \\
\hline
\end{tabular}

Table 3. Spearman Rank Correlations $\left(r_{s}\right)$ between parasite intensity and total length of bib in the Voordeita (1989)

\begin{tabular}{|crr|}
\hline Date & $\mathrm{n}$ & $\mathrm{r}_{\mathrm{s}}$ \\
\hline June & 119 & $0.27 *$ \\
July & 87 & $0.19 \mathrm{~ns}$ \\
Aug. & 43 & $0.15 \mathrm{~ns}$ \\
Sept. & 111 & $-0.08 \mathrm{~ns}$ \\
Oct. & 38 & $-0.09 \mathrm{~ns}$ \\
Nov. & 13 & $-0.28 \mathrm{~ns}$ \\
Dec. & 12 & $0.01 \mathrm{~ns}$ \\
ns $=$ not significant; $*=\mathrm{P}<0.01$ & & \\
\hline
\end{tabular}

\section{DISCUSSION}

The winter prevalences of $L$. Iusci on $0+T$. luscus fluctuated between $67.4 \%$ (October) and $76.9 \%$ (November). The maximum mean intensity was found in December (4.8). These values are high in comparison with infection levels recorded in other localities (Boxshall, 1974; Eiras, 1984; Evans et al., 1983; Tirard \& Raibaut, 1989; Tirard, 1991). It can be suggested that the Voordelta is an area where the transmission rates of $L$. lusci from intermediate host (sole) to final host (first-year class bib) are rather high. Indeed, the Voordelta area is characterized by high sole densities (Hamerlynck et al., 1993), such that significant spatial overlap of intermediate host and final host may be responsible for the high prevalences recorded.

During the winter, sole is found in deep and warmer water (more than $30 \mathrm{~m}$ depth). In 
$\longmapsto$ Mean intensity 1 parasite/fish

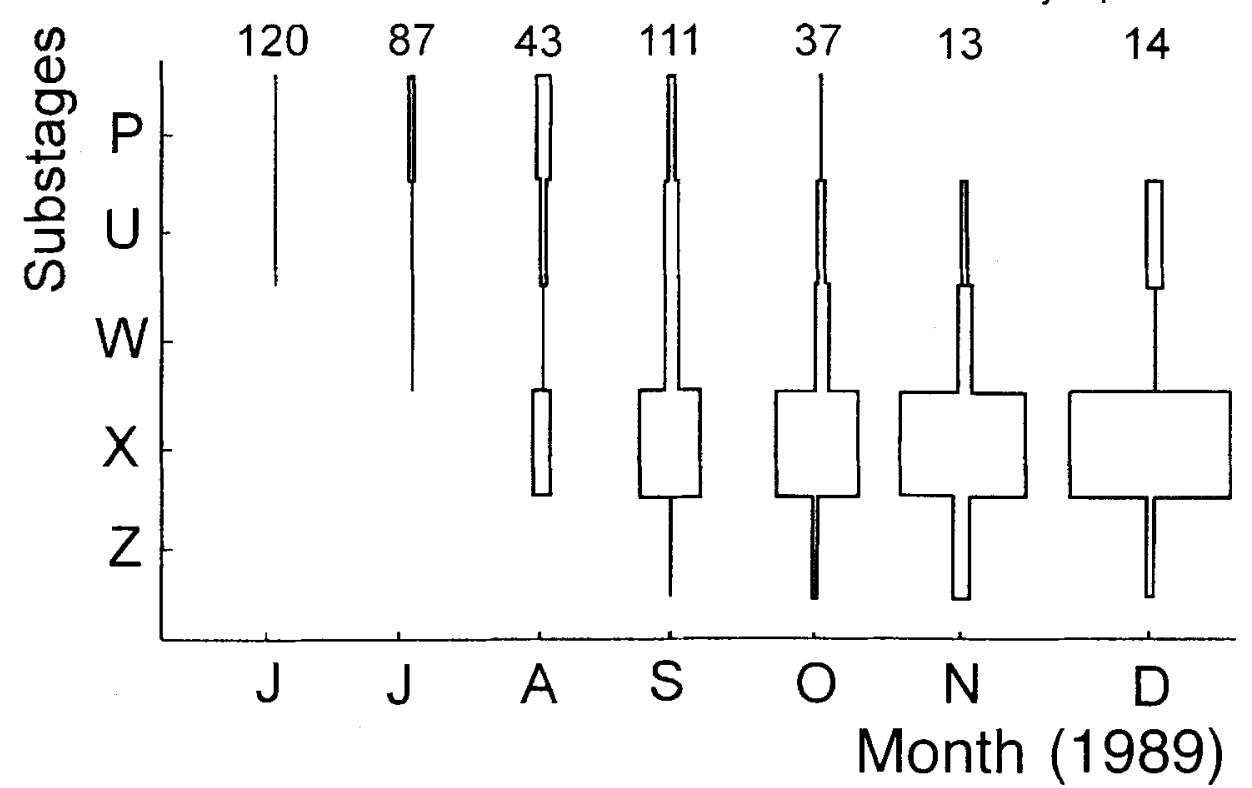

Fig. 5. Frequency of development stages of Lernaeocera lusci (Bassett-Smith, 1896) on Trisopterus Iuscus in the Voordelta 1989

spring, when the water temperature increases, they migrate to the shallow coastal zone. In this area, they are found in the gullies (between $5 \mathrm{~m}$ and $20 \mathrm{~m}$ ). The $0+$ bib on the other hand migrate to the shallow coastal zone in spring and can be found from May to December in the gullies. Thus, there are indications that a significant spatial overlap exists between sole and bib from May to September, and that may explain the high transmission rates during this period (Fig. 4). Similar explanations for the observed seasonal patterns in the transmission of infective pennella stages were put forward by Van Damme \& Hamerlynck (1992) for the related species L. branchialis. These authors assumed that the migration patterns of both intermediate (flounder) and final host (whiting) of $L$. branchialis affect the transmission success of the pennella stages.

Table 4. Seasonal variations in the number of X1, X2 and $\mathrm{Y}$ substages and in the ratio $\mathrm{J}=100(\mathrm{X} 2+\mathrm{Y}) /$ $(\mathrm{X} 1+\mathrm{X} 2+\mathrm{Y})$ for Lemaeocera lusci infecting $0+$ bib in the Voordelta (1989)

\begin{tabular}{|lrrrr|}
\hline & $\mathrm{X} 1$ & $\mathrm{X} 2$ & $\mathrm{Y}$ & $\mathrm{J}$ \\
\hline June & - & - & - & - \\
July & 3 & - & - & 0 \\
Aug. & 11 & 11 & 0 & 21 \\
Sept. & 47 & 4 & 8 & 29 \\
Oct. & 22 & 5 & 3 & 24 \\
Nov. & 21 & 5 & 0 & 19 \\
Dec. & 32 & & 3 & 20 \\
\hline
\end{tabular}




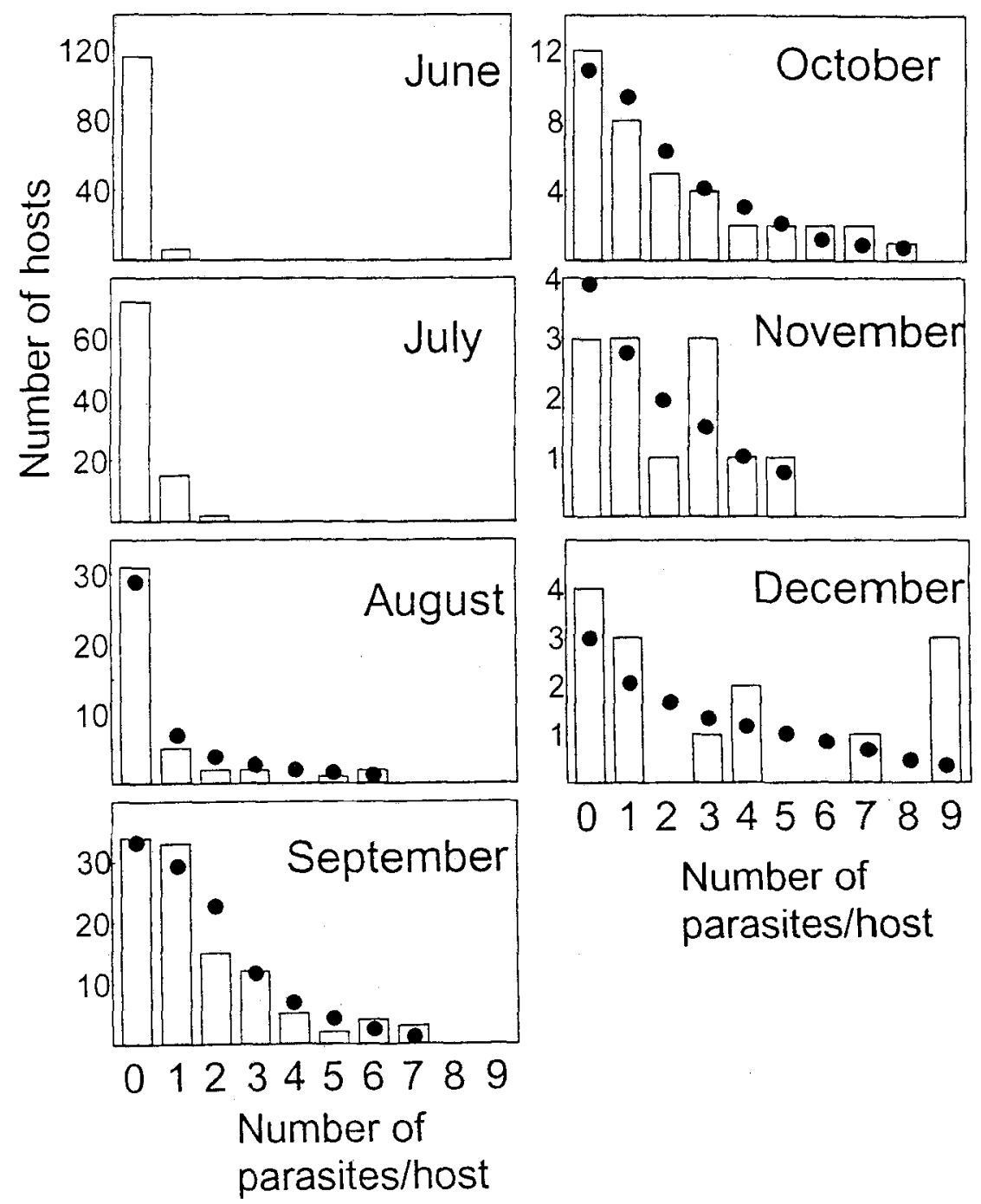

Fig. 6. Observed (bars) and expected (circles) frequencies according to the negative binomial for Lernaeocera lusci on $0+$ bib in the Oosterschelde (1989)

Slinn (1971) estimated the duration of the substages of $L$. lusci under experimental conditions. At temperatures slightly higher than in the sea, he found that the parasites passed through substages $P, U$ and $W$ within about 8 weeks. This estimate is confirmed in the present study, where $X$ substages were found as early as July and August, though the first P substages were only recovered in June. In contrast to Slinn's results, the proportion of $Z$ substages remains relatively low up to December, indicating that the majority of parasites probably overwinters on its final host.

The rather constant prevalence scores of $L$. lusci from September to December can be 
explained by the absence of further recruitment of juvenile parasites on $0+$ bib after September (Fig. 5). Yet, it can be seen in Table 3 that the abundance scores continue to increase (though non-significantly) between September and December. This may be explained by the hypothesis that heavily infected fish are more susceptible to predation and also to capture by trawlers (Van Damme \& Hamerlynck, 1992). It is clear that this factor, which can hardly be quantified, can distort some of the calculations in the present study.

Whitfield et al. (1988) demonstrated the capacity of $L$. branchialis to engage in iteroparous reproduction. The possibility to produce several sets of egg-strings, which also has been demonstrated in L. lusci (Van Damme, unpubl.), significantly increases the reproductive potential of these pennellid species. Of the $\mathrm{X}$ substages collected between August and December 1988, $77 \%$ belonged to the X1 substage, $17 \%$ to the $\mathrm{X} 2$ substage and $6 \%$ to the $\mathrm{Y}$ substage. As both $\mathrm{X} 2$ and $\mathrm{Y}$ substages were found until December, it may well be that eggs are released both in summer and in winter. However, in order to calculate the number of eggs released per time interval the effect of temperature on egg maturation should be available. Whitfield et al. (1988) provided estimates of the duration of the X substages of $L$. branchialis obtained in laboratory conditions (at $10^{\circ} \mathrm{C}$, artificial sea water). The durations of $\mathrm{X} 1, \mathrm{X} 2$ and $\mathrm{Y}$ substages were, respectively, 10 days, 2.7 days and 12 days. Though it may be unreliable to extrapolate from laboratory experiments to the field, these data illustrate the high reproductive output of pennellid species. A second factor which significantly influences egg production within $L$. lusci populations and which has been frequently overlooked is host mortality. It was found in the present study that the high mortality rates of first-year class bib (whether parasite-induced or caused by other factors) significantly reduce population size, hence, total reproduction potential of this parasite species. 'Natural' parasite mortality due to senescence or host immune responses (as reflected by the number of Z-stages found) (cf. Fig. 5) probably accounts only for a small part of total parasite mortality.

It is noticeable that $L$. lusci and $L$. branchialis exhibit different dispersion patterns within their respective host populations in the Dutch Delta-area. L. branchialis was found to be randomly distributed within 0+ whiting populations (Van Damme \& Hamerlynck, 1992), whereas L. Iusci is aggregated within $0+$ bib populations (present study). This discrepancy may follow from a range of factors, including differences in parasite-induced host mortality among those two species. However, the same authors express some doubts about the use of indices to measure dispersion of marine parasites within host populations. They suggest that the differential efficiency of the nets of research vessels, host migration patterns and spatial heterogeneity within marine habitats may hinder correct interpretation of parasite dispersion indices. Anderson \& Gordon (1982) add to these limitations the sample size, which should be large enough to reduce the significance of chance effects. Host immune responses (Van Damme \& Hamerlynck, 1992), senescence and intraspecific competition may also have profound influences on the dispersion pattern of Lernaeocera spp. Can parasite dispersion patterns provide information on the impact of parasites on host population size? Anderson \& Gordon (1982) have dealt in detail with this question, and they warn us not to over-interpret field data. Yet, L. branchialis and L. lusci exhibit certain characteristics which render them suitable for comparative studies (Van Damme et al., 1994). The pathogenic effects of both species are established, $L$. branchialis causing severe pathological damage to its host (e.g. Van den Broek, 1978) and L. lusci apparently 
not being very harmful to its host (Evans et al., 1983). Besides, they are rather long-lived (e. g. Whitfield et al. 1988; present study), and eventual parasite mortality is still observable on dissection of the host ( $Z$ stages) (Evans et al., 1983; present study). Though a full discussion of the above question is beyond the scope of this paper, this study might give a new impetus to investigations on the effect of different parasite species on both host individuals and host populations in marine habitats.

Acknowledgements. This is contribution No. 2005 of the Center for Estuarine and Coastal Ecology (The Netherlands). This study is supported by the Belgian FKFO project No. 2.008-6.88. The first author was supported by the National Fund for Scientific Research (NFWO) of Belgium.

\section{LITERATURE CITED}

Anderson, R. M. \& Gordon, D. M., 1982. Processes influencing the distribution of parasite numbers within host populations with special emphasis on parasite-induced host mortalities. - Parasitology $85,373-398$.

Bastide-Guillaume, C., Douellou, L., Romestand, B. \& Trilles, J. P., 1985. Etude comparée des deux Lernaeocera hébergés respectivement par: Merluccius merluccius et Trisopterus minutus capelanus dans le Golfe du Lion (Sète, France). - Revue Trav. Inst. Pêch. marit. 49, 143-154.

Boxshall, G. A., 1974. Infections with parasitic copepods on North Sea marine fishes. - J, mar. biol. Ass. U.K. 54, 355-372.

Eiras, J. C., 1984. Unusual attachment sites of the parasitic copepod Lernaeocera lusci (BassettSmith, 1896) upon Trisopterus luscus L. - Bull. Eur. Ass. Fish Path. 4, 28-29.

Eiras, J. C., 1986. Some aspects of the infection of bib, Trisopterus luscus (L.), by the parasitic copepod Lernaeocera lusci (Bassett-Smith, 1896) in Portuguese waters. - J. Fish Biol. 28, $141-145$.

Elliot, J. M., 1977. Some methods for the statistical analysis of samples of benthic invertebrates. Freshwater Biol. Ass., Ambleside, Westmoreland, $160 \mathrm{pp}$.

Evans, N. A., Whitfield, P. J., Bamber, N. \& Espin, P. M., 1983. Lernaeocera lusci (Copepoda: Pennellidae) on bib (Trisopterus luscus) from Southampton Water. - Parasitology 86, 161-173.

Hamerlynck, O. \& Hostens, K. 1993. Growth, production and consumption in $0+$ group bib Trisopterus luscus and whiting Merlangius merlangus in a shallow coastal area of the SW Netherlands. - ICES J. mar. Sci. 50, 81-91:

Hamerlynck, O., Hostens, K., Arellano, R. V., Mees, J. \& Van Damme, P. A., 1993. The mobile epibenthic fauna of soft bottoms in the Dutch Delta (south-west Netherlands): spatial structure. Neth. J, aquat. Ecol, 27, 343-358.

Heegaard, P., 1947. Contribution to the phylogeny of the arthropods: Copepoda. - Spolia zool. Mus. haun. 8,1-236.

Kabata, Z., 1963. New host record for Lernaeocera lusci (Bassett-Smith, 1896). - Crustaceana 6 , $159-160$.

Kabata, Z., 1979. Parasitic Copepoda of British fishes. The Ray Society, London, 2018 pp.

Margolis, L., Esch, G. W., Holmes, A. M., Kurie, A. M. \& Schad, A. D., 1982. The use of ecological terms in parasitology. - J. Parasit. 68, 131-133.

Pilcher, M. W., Whitfield, P. J. \& Riley, J. D., 1989. Seasonal and regional infestation characteristics of three ectoparasites of whiting, Merlangius merlangus L., in the North Sea. - J. Fish Biol. 35 , $97-110$.

Slinn, D. J., 1971. An infestation of adult Lernaeocera (Copepoda) on wild sole, Solea solea, kept under hatchery conditions. - J. mar. biol. Ass. U.K. 50, 787-800.

Sproston, N. G. \& Hartley, P. H. T., 1941. The ecology of some parasitic copepods of gadoids and other fishes. - J. mar. biol. Ass. U.K. 25, 361-392.

Taylor, L. R., 1961. Aggregation, variance and the mean. - Nature, Lond. 189, 732-735.

Tirard, C. \& Raibaut, A., 1989. Quelques aspects de l'écologie de Lernaeocera lusci (Bassett-Smith, 1896), copépode parasite de poissons Merlucciidae et Gadidae. - Bull. Ecol. 20, 289-294.

Tirard, C., 1991. Biodiversité et biogéographie évolutive dans les systèmes hôtes-parasites: le 
modèle Gadiformes (Téléostéens). - Copépodes et Monogènes. Thèse de doctorat, Univ. de Montpellier, $148 \mathrm{pp}$.

Van Damme, P. A. \& Hamerlynck, O., 1992. The infection dynamics and dispersion pattern of Lernaeocera branchialis L. on 0+ whiting (Merlangius merlangus L.) in the Oosterschelde. - J. Fish Biol. 41, 265-275.

Van Damme, P. A., 1993. The suprapopulation dynamics of the marine fish parasites Lernaeocera Iusci and L. branchialis (Copepoda, Pennellidae). Ph. D. Thesis, Univ. of Leuven, Belgium, $253 \mathrm{pp}$.

Van Damme, P. A., Ollevier, F. \& Hamerlynck, O., 1994. Pathogenicity of Lernaeocera lusci and $L$. branchialis in bib and whiting in the North Sea. - Dis. aquat. Org. 19, 61-65.

Van den Broek, W. L. F., 1978. The effects of Lernaeocera branchialis on the Merlangius merlangus population in the Medway estuary. - J. Fish Biol. 13, 709-715.

Whitfield, P. J., Pilcher, M. W., Grant, H. J. \& Riley, J., 1988. Experimental studies on the development of Lernaeocera branchialis (Copepoda: Pennellidae): population processes from egg production to maturation on the flatfish host. - Hydrobiologia 167-168, 579-586. 